\title{
Techno-economic Analysis of Rotor Flettner in Container Ship 4000DWT
}

\author{
Agoes Santoso $^{1}$, Muhammad Badrus Zaman ${ }^{2}$, Arrijal Yudha Prawira ${ }^{3}$
}

\begin{abstract}
This technology is very simple, cylindrical in shape, applied in the upper deck, and rotated by the electrical motor. This technology uses wind energy and applicating magnus effect to create propulsion force. Rotor flettner depends on the condition of the sea wind. The designer has to check the weather condition in its route before make a design of rotor flettner. This kind of technology is not only useful for the economic side, but also, for the environment. Rotor flettner can reduce the emission of a ship. It helps to gain some power to increase in fuel saving.The emission can be decreased by the increasing of fuel saving. So, this technology is a kind of environmentally friendly technology that can be used for the future innovation.
\end{abstract}

Keywords-CFD, economic techno, emission, flettner rotor

\section{INTRODUCTION ${ }^{1}$}

$\mathrm{G}$ reen technology in need for the recent years has becomes the very first priority because it needs to create healty environment while technology grows quickly. One of the environmentally friendly technology is a green technology applied in a ship. As we know, ships need so much energy for the propulsion.

Years by years, the consumption of fuel in ship is getting bigger, see figure 1. It causes the increasing rate of $\mathrm{CO} 2$ in the sea surface. It showed in the graphic below, see figure 2 . not proper yet to become the main energy sources, but, it can very helpful to become an alternative energy.

Study about the application of flettner rotor analysis has already been done by some researchers. However, this study will talk about different side of flettner rotor.

This study will analayze about economical side of flettner rotor that used by container carrier with DWT 4000 ton.

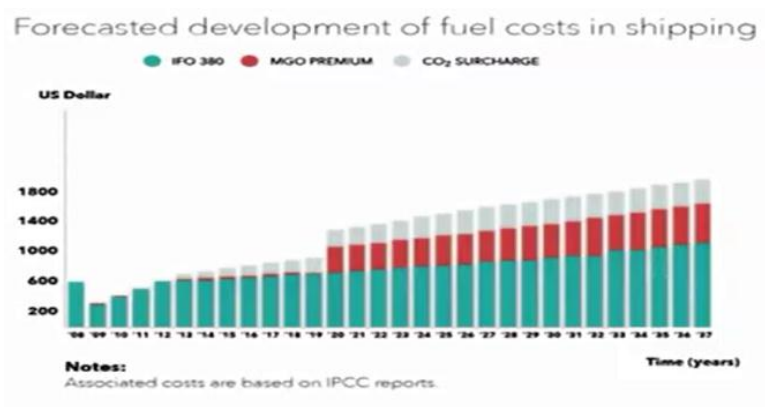

Figure 1. The increasing graphic of fuel consumption in the last few years

It needs to invent some alternative energy to decrease the impact of those much energy. One of them is rotor flettner. Rotor flettner is a wind assisted propulsion for ship that can strong enough to make some propulsion force for the ship. However, in economical analysis, it is

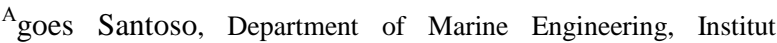
Teknologi Sepuluh Nopember, Surabaya 60111, Indonesia, Email : agoes@its.ac.id

M. Badrus Zaman is with Department of Marine Engineering, Institut Technologi Sepuluh Nopember, Surabaya 60111, Indonesia. Email:druz_zaman@ne.its.ac.id

Arrijal Yudha Prawira, Department of Marine Engineering, Institut Teknologi Sepuluh Nopember, Surabaya 60111, Indonesia, Email: miyudho@gmail.com
}

\section{LITERATURE REVIEW}

Rotor flettner is a kind of mechanical prupulsor for ships that assisted by the wind. This technology is cylindrical in shape. Rotor flettner uses magnus effect to create some propulsion force [1].

Wind that blows past the cylinder will cause the pressure difference between the direction of the wind around the cylinder and opposite to the rotation cylinder that causing the thrust.

Flettner rotor is one type of mechanical propulsor vessel utilizing wind power [10]. This device consists of a large vertical cylinder. The working principle of this device utilizes magnus effect, ie, the wind that blows past the cylinder will cause the pressure difference 
between the direction of the wind around cylinder and opposite to the rotation cylinder that causing thrust for

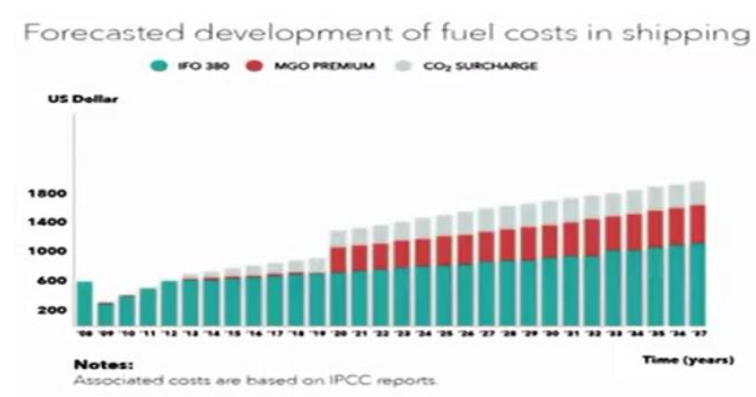

Figure 2 The increasing graphic of $\mathrm{CO} 2$ level aboce the ocean

the ship.

Installation of this rotor flettner must consider the conditions and wind direction in order to obtain optimum efficiency. Ships using Fixed Pitch Propeller has the advantage in the result of the installation of this rotor flettner than using other propeller types. At the time of sailing using flettner this rotor, steering the ship must always be controlled in order to stay on the right path.

The benefits of the application of rotor flettner on the ship is able to save on fuel usage with a percentage of $10-30 \%$ depending on the cruise line to be taken. Saving fuel will reduce the emissions such as $\mathrm{CO} 2$, SOx, NOx and other emissions. Rotor flettner is acting as an auxiliary energy for ship propulsion system and could even perform up to $100 \%$ as a propulsion system with optimal wind conditions. Thus, the rotor flettner can serve as an independent propulsion system [2].

The effectiveness of this rotor flettner depends on:

1. The cruise line

2. wind speed

3. Wind Direction

There are several advantages obtained from the use of rotor flettner on ships, which are:

1. Does not require additional crew

2. The system used to run automatically

3. No adverse effects occurred in charge

4. 10-30\% fuel saving per year

5. Produce lower emissions than conventional vessels

\section{ECONOMIC TECHNO ANALYSIS}

Economic techno is about on how to make a decision (decision making) which is limited by a variety of problems associated with an engineer to produce the best choice from a wide range of alternative options. Decisions taken by a process of analysis, technical and economic calculations [3] [4].

Engineering used to say the profession / discipline where knowledge of mathematics and natural sciences gained by study, experience, and practices used wisely in developing ways to economically use materials and natural resources for the benefit of man. The definition of the economic aspects of the engineering emphasis on physical aspects. Obviously, that basically the economy is part of a well-executed engineering [5].

Alternatives arise because of the limitation of resources (human, material, money, machine, opportunity, etc.). With a wide range of existing alternatives, so it needed a calculation to obtain the best economic choice, both when comparing different design alternatives, make capital investment decisions, to evaluate the financial opportunities and so forth.

Techno economic analysis involves making a decision on the various uses of limited resources. The consequences of the results of decisions are usually impact far into the future, the consequences can not be known with certainty, a decision-making under uncertainty [8] [9]. So it's important to know:

1. prediction of future conditions.

2. The development of technology.

3. Synergies between projects funded.

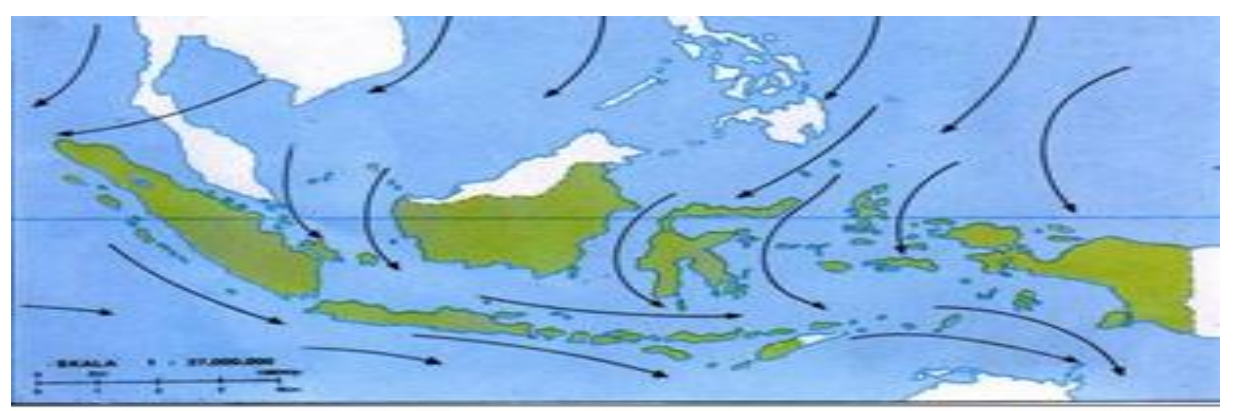

Figure 3. Wind condition on wet season in Indonesia 
Because the application of engineering activities generally require relatively large investment and longterm impact on the activities of his followers, the implementation of these activities requires strategic decisions that require consideration technical and economical and rational. Therefore, Techno Economic Sciences were also considered as a means of decision support (Decision Making Support) [9].

\section{A. Study Area}

Study area of this reserach is Surabaya-Balikpapan. Based on the figure 3-5, wind conditions across the region cruise Surabaya-Balikpapan support the functions of performance of flettner rotor based on the direction and force of wind flow generated by the movement of the rotor [6].

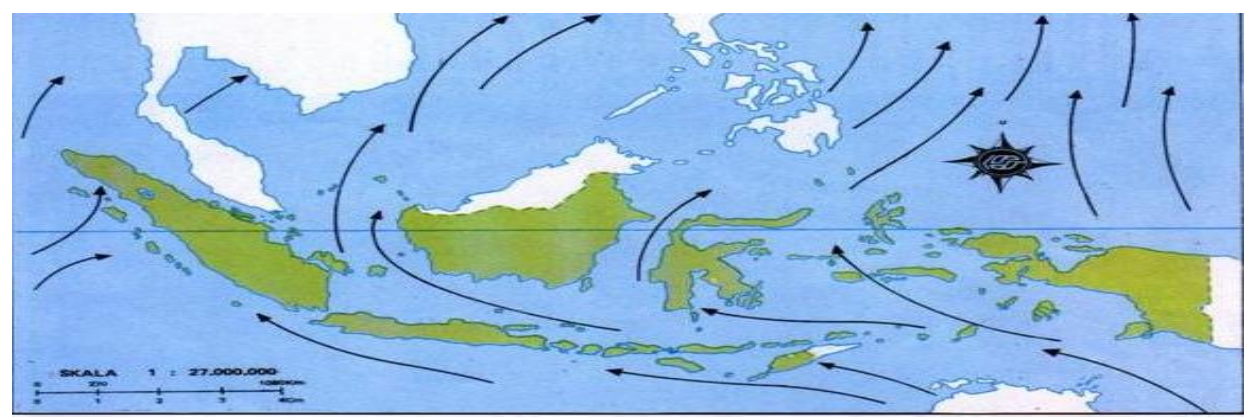

Figure 4. Wind condition on dry season in Indonesia

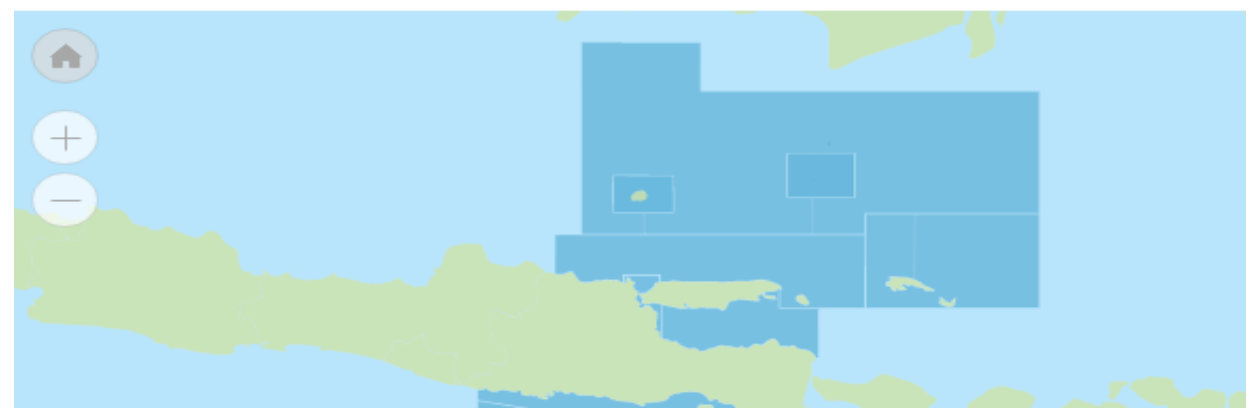

Figure 5. Selected area of the study

\section{A. Numerical Performance Model}

Numerical performance model. The power consumed by the motor, and the lift and drag forces acting on the cylinder determine the amount of main engine power the rotor is able to replace. The thrust gained from the rotor is calculated as the projection of the sum of the lift and drag force and, respectively, onto the course of the ship. The magnitudes of the lift and the drag force, and the power delivered by the rotor and to the rotor, respectively, are given by the following equations:

$1=1 / 2 \rho$ Ava $2 \mathrm{CL}$

$\mathrm{d}=1 / 2 \rho \mathrm{A}$ va $2 \mathrm{CD}$

pl\&d $\quad=(1+d) . V s$

pmotor $\quad=1 / 2 \rho \mathrm{A}$ va3 $\mathrm{CM} \alpha$

The defining parameters are the lift, drag, and moment coefficient,CL,CD and CM (in line with anecdotal evidence and preliminary CFD results, see below), respectively; the rotor is a plain cylinder, without end plates, andit has a vertical cross sectional area A, which is the height $\mathrm{h}=18 \mathrm{~m}$ times the diameter $\mathrm{d}=3 \mathrm{~m}$, and the spin ratio (the ratio of the rotor surface speed and the apparent wind speed)a $=5,23$. Vship is the ship's velocity vector, $\mathrm{Va}$ is the apparent wind speed,and $\mathrm{q}$ is the density of air. If the power contribution is smaller than that from the drag force alone it is assumed that the rotor is switched off. The power contribution pprop is calculated as the difference between the power delivered by the Flettner rotor and the power that is consumed by the motor to rotate it:

pprop $=$ pl\&d - pmotor

\section{B. Ship Resistance Calculation}

\section{B.1 Volume Displasment}

Displasmen volume is the volume of water displaced by the hull. Where the formula used to find the volume displasmen are:

$\nabla(\mathrm{m} 3)=\mathrm{CbWl} \times \mathrm{LWL} \times \mathrm{B} \times \mathrm{T}$

\section{B.2 Displasment Weight}

Displasmen weight is the weight of the volume of water displaced by the hull. So the weight of displaced 
water volume of the weight of the ship. Where the formula used to find the weight displasmen are:

$\Delta($ Newton $)=\boldsymbol{\nabla} \times \rho$ air laut

\section{B.3 Wet Surface Area}

\section{B.4 Froud Number}

Froud number (Fn) need to know to define that linear function of the Fn is a standard LCB. Fn itself will be used to read a chart 5.5.25 on the book Resistance and Propulsion of Ships [7]. The following formula to find Fn:

$\mathrm{Fn}=\mathrm{V} / \sqrt{\mathrm{gLwl}}$

\section{B.5 Reynolds Number}

Reynolds number needs to be known, because it will serve to seek frictional resistance later. The following formula to find $\mathrm{Rn}$ :

$$
\mathrm{Rn}=(\mathrm{V} \times \mathrm{Lwl}) / \mathrm{Vk}
$$

\section{B.6 Friction Resistance (Friction Coefficient)}

Frictional resistance $(\mathrm{CF})$ is a resistance because of the friction caused by the fluid which has a viscosity, and the viscosity is a cause of friction with the surface ship. Actually, to look for frictional resistance, there are two ways, namely by calculating according to the formula, and by looking at the picture on the book Resistance and Propulsion of Ships (Harvald, 1992) by entering the value of the speed of the ship, and also the length of the ship. But in this design, will use the formula, because it more closely.

\section{B.7 Residual Resistance(Coefficient resitance)}

Residual drag coefficient (CR) for a standard vessel can be taken from the diagram fig.5.5.5 - 05/05/13 on the book Resistance and Propulsion of Ships (Harvald, 1992). Before looking for the rest of the resistance in the diagram, should determine the value, the value of $\beta$, and the value of $\varphi$.

\section{B.8 Additional Resistance}

Although there have been previous CF correction, but the correction has not been included in the correction of the surface roughness of the ship. Because remember that the surface is not as smooth with the surface ship models. Extra correlation coefficient custody for ship models are generally determined by various forms of correction, there is a direct set a price of $\mathrm{CA}=4$, and there is also dependent on the length of the vessel is designed. This time the book Resistance and Propulsion of Ships (Harvald, 1992) recommends to correct by referring of displasmen designed vessels, because some argue that the correction is designed according to the reference displasmen more appropriate vessel. Here below is the value of $\mathrm{CA}$ is given in accordance with the reference of displasmen ship:
In the book Resistance and Propulsion of Ships (Harvald, 1992), a wet surface for normal merchant ship can be calculated using the following formula:

$\mathrm{S}=1,025 \mathrm{Lpp}(\mathrm{Cb} \times \mathrm{B}+1,7 \mathrm{~T})$

Since the value of displasmen designed vessels this time located at between $1,000 \mathrm{t}-10,000 \mathrm{t}$, it must be done interpolation. So that later we will get the value of CA correctly.

\section{B.9 Air Resistance}

The amount of air resistance is generally not very important, and efforts should be made to get the exact calculation may not be adequate to the importance of the influence of the air. According to the book Resistance and Propulsion of Ships (Harvald, 1992), if the data on the wind in the design is not known it is recommended for the correction of air resistance as follows:

$\mathrm{CAA}=0.00007$

\section{B.10 Steering Resistance}

For steering resistance value is no special formula to look for it, in the book Prisoner and Propulsion of Ships (Harvald, 1992) is given a value as follows:

$\mathrm{CAS}=0.00004$

But the actual value of the steering resistance could be ignored in a stable ship in reasonable condition. It looks above correction value is very small, because in the initial design, the correction is generally already included in the additional resistance.

\section{B.11 Total Resistance}

To calculate the total resistance of ships, it should be added together before all the coefficients had been sought and has also been obtained. For the total coefficient value is as follows:

$$
\mathrm{CT}=\mathrm{CF}+\mathrm{CR}+\mathrm{CA}+\mathrm{CAS}+\mathrm{CAA}
$$

After a total coefficient value is obtained, then the next can be calculated from the value of total resistance vessels as follows:

$\mathrm{RT}=\mathrm{CT}\left(1 / 2 \rho \mathrm{V}^{\wedge} 2 \mathrm{~S}\right)$

$\mathrm{RT}$ service $=(1+15 \%) \times \mathrm{RT}$

\section{Propulsion Force Calculation}

Before obtaining power saving, it needs to obtain propulsion force calculation first. The formula is shown below :

$$
F_{p}=(L x \sin \beta+D x \cos \beta)
$$

While $\mathrm{L}$ is lift force, $\mathrm{D}$ is drag force, and $\beta$ is the apparent wind. 


\section{RPM Flettner Rotor vs Force}
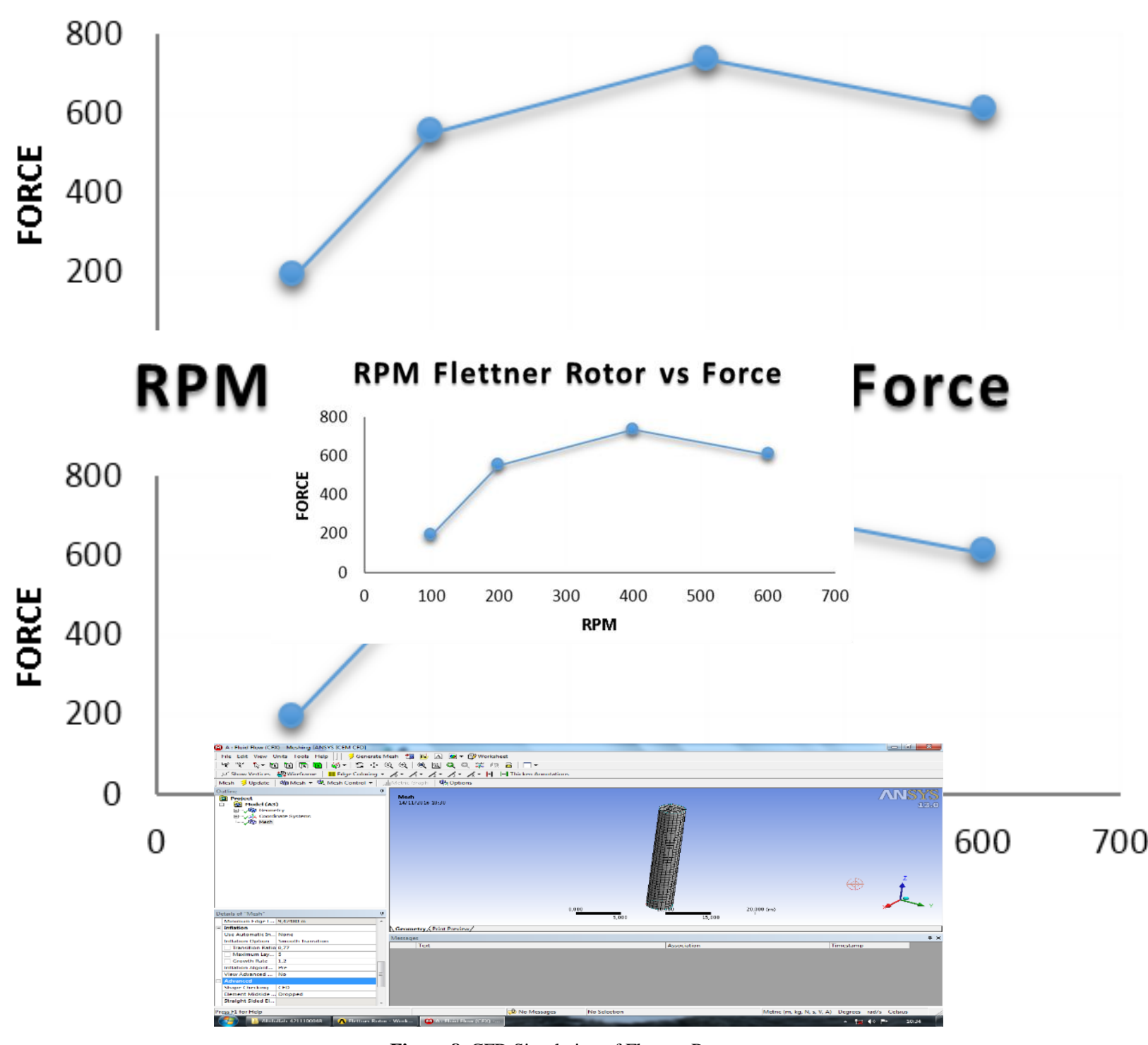

Figure 8. CFD Simulation of Flettner Rotor

\section{Rotor Flettner's Calculation}

Based on the chart in figure 7 , the higher the rotation flettner rotor, then, the greater the force generated. However, when the rotation reaches 600 RPM, the force generated has decreased.

The value of RPM used for the analysis based on the results of the largest thrust force, namely when flettner rotor is rotated at $400 \mathrm{RPM}$ and generate a force of 736 N.

From the simulations in CFD in figure 8 , there are some data that can be collected to calculate the power of rotor flettner. The data:

1. Height of rotor flettner $=18 \mathrm{~m}$

2. Diameter of rotor flettner $=3 \mathrm{~m}$

3. $\mathrm{RPM}=400$

4. Lift $=736 \mathrm{~N}$

5. Drag $=11,776$

6. Coefficient Moment $=0,335$

From the datas above, it can be calculated for the rotor flettner's power using the calculation in section 3 . The result of the calculation shown in table 3 .

1. The combination of power from the lift and drag amounted to 5002.621 watt
2. Power required to rotate the rotor flettner of 400 RPM is 825.286 watt

3. Power contributed by flettner rotor amounted to $4177.336 \mathrm{~N}$.

Once the value of BHP's new is collected (see table 4), power saving calculation can be determined according to figure 6 , then, gained power saving amounting to $0.038 \%$. 
TABLE 3.

ROTOR FLETTNER'S CALCULATION

\begin{tabular}{cc}
\hline $\mathrm{p}_{\text {l\&d }}$ & $5002,621 \mathrm{~N}$ \\
\hline $\mathrm{p}_{\text {motor }}$ & $825,286 \mathrm{~N}$ \\
\hline $\mathrm{p}_{\text {prop }}$ & $4177,336 \mathrm{~N}$ \\
\hline
\end{tabular}

TABLE 4.

SHIP'S POWER AFTER ROTOR FLETTNER HAS BEEN MOUNTED

\begin{tabular}{cc}
\hline Ship's total resistance ( Rt service ) & $106,06 \mathrm{kN}$ \\
\hline EHP & $709,54 \mathrm{~kW}$ \\
\hline DHP & $1210,09 \mathrm{~kW}$ \\
\hline SHP & $890,02 \mathrm{~kW}$ \\
\hline BHP & $1210,094 \mathrm{~kW}$ \\
\hline
\end{tabular}

\section{CONCLUSION}

Based on the results of the discussion above has been referring to the data and relevant references, then, it can be deduced for the results of studies that have been carried out is as follows:

1. Power required to rotate the rotor flettner with a speed of 400 RPM is equal to 825.286 watts

2. Power Contribution generated amounted to 4177.336 watts

3. The higher the rotation flettner rotor, then, the greater the force generated. However, when the rotation reaches $600 \mathrm{RPM}$, the force generated has decreased.

4. According to the techno economic analysis calculation of the power saving has been done on the cruise lines Surabaya-Balikpapan, Rotor Flettner less contributes to fuel savings as an alternative energy because it provides the effectiveness of $0.038 \%$.

Based on the results of the discussion and conclusions that have been obtained regarding the techno economic analysis rotor flettner on container ships with cruise lines Surabaya-Balikpapan, still required some further action in order to achieve effective use flettner rotor, including:

1. The cruise line extended. Suggested taking samples of international shipping

2. Increase the number of rotor and carried out further analysis of variations in the number of rotor.

\section{REFERENCES}

[1] Craft, T. J. 2012. "Back to The Future : Flettner-Thom Rotors for Maritime Propulsion ?" in: Proceedings of 7th
Internat. Symposium on Turbulence Heat \& Mass Transfer; 24 Sep 2012-27 Sep 2012; p. 1053-1056.

[2] Guo-ping, Z. 2009. "Research \& Design of Offshore Standby Vessel With Electric Propultion". Ship building of China.

[3] Harun, Hamran. 2011. "Wind Assisted Propulsion for Fue Saving". Disertasi Teknik Kimia Universitas tenologi Malaysia, Malaysia.

[4] Ilhami, O, P., 2015 "Analisa Aplikasi Flettner Rotor Pada Offshore Support Vessel Panjang 56 Meter Dengan Metode CFD”. Tugas Akhir Sistem Perkapalan ITS, Surabaya

[5] Iskandar, B., dkk. 2010. "Tekno Ekonomi Pembuatan Perahu Fiberglass Di Desa Cikahuripan Kecamatan Cisolok, Sukabumi”. Tugas Akhir Fakultas Perikanan dan Kelautan, IPB Bogor.

[6] Kecepatan Angin Pulau Jawa diunduh dar www.maritim.bmkg.go.id Pada 21 desember pukul 19.20

[7] Rizzo, F. 1925. "The Flettner Rotor Ship in The Light of The Kutta-Joukowski Theory and of Experimental Results". Naca; $p$. 9-20.

Sv. Aa, Harvald. 1992. "Tahanan dan Propulsi Kapal” Airlangga University Press, Surabaya.

[8] The Mega Ships of Tomorrow May Be Driven by Technology From the Past. Diunduh dari www.gizmodo.com Pada 3 desember pukul 15.30

[9] Traut, M., dkk. 2014. "Propulsive power contribution of a kite and a Flettner rotor on selected shipping routes". Applied Energy.113:362-372

[10] H. Prastowo, A. Santoso, and A. Arya, "Analysis and Optimation Hydrofoil Supported Catamaran (HYSUCAT) Size 25 Meter based on CFD Method," Int. J. Mar. Eng. Innov. Res., vol. 1, no. 1, Dec. 2016 